\title{
Assessment of inhibiting features of some commercial bactericides
}

\author{
R.V. Kashkovskiy, ${ }^{1}$ R.V. Igoshin ${ }^{2}$ and A.O. Sayapin ${ }^{3}$ \\ ${ }^{1}$ Gasprom VNIIGAZ, Proektiruemiy proezd 5537, vlad. 15, str. 1, Razvilka village, \\ 142717Moscow region, Russia \\ ${ }^{2}$ Gasprom PJSC, 16 Nametkina St., 117997Moscow, Russia \\ ${ }^{3}$ Gubkin Russian State University of Oil and Gas, 65 Leninsky Prospekt, \\ 119991 Moscow, Russia \\ E-mail: roman.kashkovskiy@gmail.com
}

\begin{abstract}
The study deals with bacteriological and anti-corrosion features of three domestic bactericidal corrosion inhibitors (CI) in presence of sulphate-reducing bacteria in an oxygen-depleted and $\mathrm{CO}_{2}$-containing nutritent medium. Efficacy of compositions under study in both inhibiting bacterial growth in an environment and decreasing total corrosion rate in structural steel was measured experimentally. Particular attention in discussion of results was paid to applicability conditions of optical evaluation method for bactericidal features of additives.
\end{abstract}

Key words: microbiological corrosion, structural steel, corrosion inhibitor, bactericide, sulphate-reducing bacteria.

Received: January 14, 2018. Published: March 12, 2018

doi: $\underline{10.17675 / 2305-6894-2018-7-2-1}$

Numerous studies proved that microorganisms inhabiting operation environment of metalworks are capable to stimulate or slow down chemical and electro-chemical processes of their destruction, either enhancing or inhibiting them [1]. Promotion action of bacteria and products of their metabolism on these processes is referred to as metal biocorrosion or microbiological corrosion. Both underground and above-ground constructions, petroleum and gas industrial equipments, shore and harbour installations, pipelines in contact with ground and water environment, are subject to the corrosion. Such biodamages can reduce service life and safety of constructions and equipments, lead to their failures and unsafe operation, impose significant economical and ecological damage [2].

It is well known that most of Gazprom's trunk gas pipelines (TGP) have operation life span longer, than rated durability of insulation coatings along their route. Local corrosive damages on steel surfaces can be often detected under detached coatings of TGP [3], including when causes of accidents being investigated (Figure 1). In this connection, studies on biocorrosion impacts on pipe steel under detached protective coating in underground lengths of long-time operated TGP are of particular interest. 


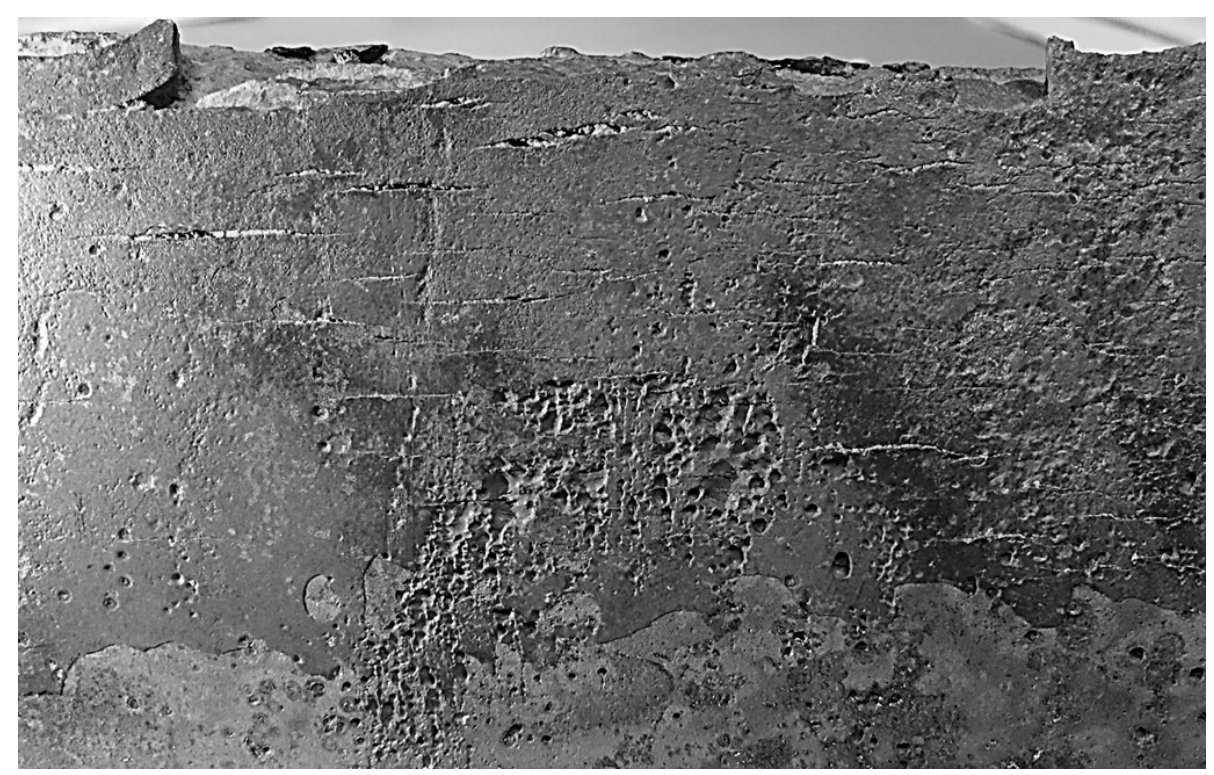

Figure 1. A fragment of wrecked pipe.

Theoretical conceptions of microbiological corrosion processes have been discussed more than once in engineering literature; this topic can be found both in domestic [2, 4], and in world periodicals [5-8], and also it is routinely discussed at international scientific forums $[9,10]$. Authors of papers involved, would specifically mention evident corrosion activity by sulphate-reducing bacteria (SRB), so this bacterial species was taken as a subject of various scientific studies often. These microorganisms are capable to biogenic sulphate reduction during their anaerobic respiration, wherein final products are $\mathrm{S}^{2-}$ ions and namely $\mathrm{H}_{2} \mathrm{~S}$. Overall, chemical reaction, in this case, is as follows [8]:

$$
4 \mathrm{Fe}+\mathrm{SO}_{4}^{2-}+4 \mathrm{H}_{2} \mathrm{O} \rightarrow \mathrm{FeS}+3 \mathrm{Fe}(\mathrm{OH})_{2}+2 \mathrm{OH}^{-}
$$

It was reported in [11] that under favourable living conditions for SRB, up to $2 \mathrm{~g} / \mathrm{l}$ $\mathrm{H}_{2} \mathrm{~S}$ may accumulate in the medium, and in addition to usual sulphates, these bacteria may use sulphite, thiosulphate, and trithionate ions as electron acceptors.

There were some cases, when bacteria present in the medium resulted in reduced efficacy of anti-corrosion protection measures. For example, downclassing of steel $E_{\text {cor }}$ in the presence of SRB can lead to such effect, for in this case, cathode polarisation value decreases in naked lengths or sites of full delamination of insulation coating on gas pipeline being protected $[12,13]$.

Application of negative potential to a steel cannot influence concentration of plankton biomass floating in the solution, but quantity of adhered SRB cells can noticeably increase. Bacteria connected to metal substrate are capable to take up electrons released during oxidation of iron and, consequently, enhance anodic corrosion process. Following assimilation of electrons takes place in SRB cell cytoplasm as sulphate reduction process being catalysed by a specific cell protein - cytochrome [14]. Thus, some necessary 
conditions are formed on such surface sites for pitting corrosion, even in the presence of cathodic protection (CP) of the metal (Figure 2) [15].

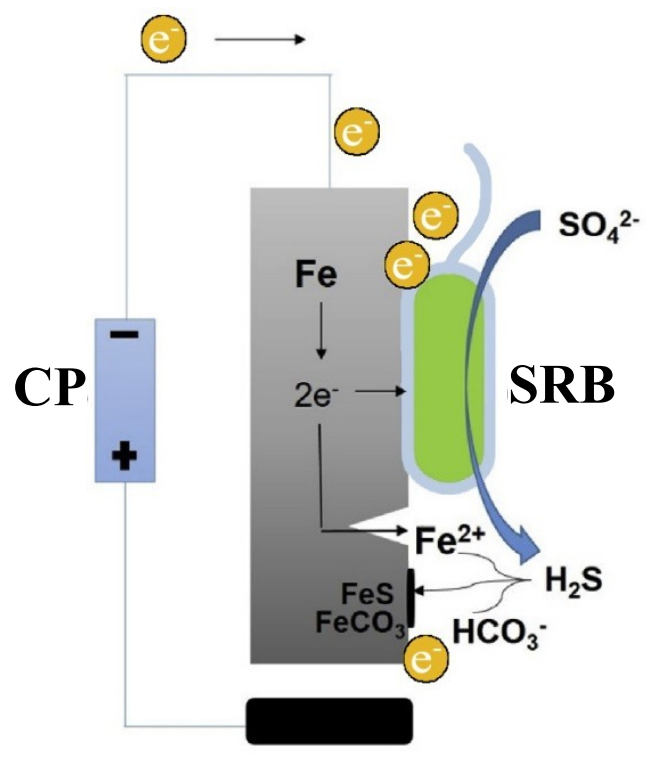

Figure 2. Diagram of electrochemical processes involving adhered SRB cell on cathodeprotected steel surface.

Biogenic sulphide, in its turn, when appearing in ground or under-film electrolyte will enhance progress of local corrosion processes on steel pipeline surface under detached insulation. The above phenomena are undoubtedly dangerous in regard to possible intensification of other corrosion and stress-corrosion processes in operated lengths of TGP [16-18]. Hence, in order to reduce current operational risks in TGP, development and introduction of preventive measures of protection against biocorrosion are required, as well as studies on bacterial impacts on corrosion and stress-corrosion kinetics of gas pipeline damages for reliable planning of diagnostic procedures.

Application of special functional additives capable to inhibit both bacterial growth and corrosion is a very effective and advanced method for protection of metals against microbiololgical corrosion. Substances that belong to different chemical classes may have such universal features. They include:

- aliphatic and polycyclic amines [19], quaternary ammonium salts [20],

- acylated alkyl dienes, salts of fatty carbonic acids, B-, As-, Sn-, Hg-containing substances, nitro furan resins [21], formalin [22];

- chlorinated phenols, silver sulphonates [21], substituted sulfamides [23];

- derivatives of heterocyclic substances (pyrimidine, isothiazoline) [23], and a number of other substances.

Among up-to-date studies, which have results of wide and important practical significance, joint works of specialists from Gazprom VNIIGAZ LLC and IPhChE (the Russian Academy of Sciences) are worth to be noticed. Particularly, in a series of papers 
$[13,24]$, potential feasibility and efficiency of corrosion inhibitor (CI) application within protective coating during field re-insulation of pipelines under SCC for conservation of cracks [25] was shown. However, some deeper studies are still necessary on antimicrobial efficacy of inhibiting composition applied in coatings.

In this connection, an objective of the present study was both to develop and evaluate procedures of bacteriological corrosion examination, and to assess efficacy of commercially available bactericidal corrosion inhibitors in protection of steel against corrosion in bacterially populated media.

\section{Methods and Procedures}

Domestic corrosion inhibitors Soncor 9920B, Soncide 8102B, and Soncide 8103A, below referred to as "B1", "B2", and "B3", respectively, were subjects in the study. Bacteriological studies on effects of additives were performed using SRB of Desulfovibrio species, and were based on measuring optical density of inoculated inhibited and background media.

Used nutrient medium: standard medium by Postgate $\mathrm{B}$ composed as follows: sodium lactate, $3.5 \mathrm{~g} / \mathrm{l}$; yeast extract, $1 \mathrm{~g} / 1 ; \mathrm{NH}_{4} \mathrm{Cl}, 1 \mathrm{~g} / \mathrm{l} ; \mathrm{CaCl}_{2}, 0.72 \mathrm{~g} / 1 ; \mathrm{Na}_{2} \mathrm{SO}_{4}, 0.921 \mathrm{~g} / \mathrm{l}$; $\mathrm{KH}_{2} \mathrm{PO}_{4}, 0.5 \mathrm{~g} / \mathrm{l} ; \mathrm{MgSO}_{4} \cdot 7 \mathrm{H}_{2} \mathrm{O}, 2 \mathrm{~g} / \mathrm{l} ; \mathrm{FeSO}_{4} \cdot 7 \mathrm{H}_{2} \mathrm{O}, 0.5 \mathrm{~g} / \mathrm{l} ; 1 \% \mathrm{Na}_{2} \mathrm{~S}$ solution in $1 \%$ $\mathrm{NaHCO}_{3}, 5 \mathrm{ml} / \mathrm{l} ; \mathrm{pH} 7-7.5$ [26]. The nutrient medium was preliminary sterilised for 30 minutes at $t=121{ }^{\circ} \mathrm{C}$ in the autoclave MLS-3020U, and then inoculated by adding $10 \%$ SRB subculture. Additionally and if required, aliquots of bactericidal inhibitors were added to the solution to generate concentration series of $0.001 \% ; 0.01 \% ; 0.1 \%$.

Background and inhibited media thus prepared and inoculated with SRB were placed in sterile tubes, sealed with plugs, and exposed in air thermostat at $t=31-33^{\circ} \mathrm{C}$. Subsequently, in defined time intervals, tubes were taken from the thermostat by one of each tested medium series, and optical densities were measured. Measurements were made on photometer KFK-3-01 at light wavelength $\lambda=425 \mathrm{~nm}$ in cells of $10 \mathrm{~mm}$ light path, against distilled water. Results were later normalised to initial optical density values $\left(A_{\tau=0}\right)$.

Bactericidal effects of additives were evaluated by bacterial growth inhibition rate, $N(\%)$, calculated by equation below:

$$
N_{\tau}(\%)=\frac{A_{\mathrm{bg}, \tau}-A_{\tau}}{A_{\mathrm{bg}, \tau}} \cdot 100,
$$

where: $\quad A$ - optical density, relative units;

"bg" - an index showing background solution;

" $\tau$ " - an index showing time point $\tau$.

Corrosion tests were performed on specimens of structural steel Grade St20 [27] and steel welding wire Grade Sw08A [28]. 
Steel corrosion rates were evaluated using several procedures. Instantaneous rates of steel corrosion were evaluated using linear polarisation resistance (LPR) measurement technique of steel electrodes immersed in test medium. Carrying out the test was almost similar to previously described procedures [29]. However, in order to ensure anaerobic conditions, special measurement cells were designed that prevented air penetration into test medium. Measurements were taken using Monicor-2 Device.

Integral values of corrosion rates were measured gravimetrically and analytically. In the first case, specimens before and after tests were treated applying procedures similar to described in [30], and corrosion rates $K$, in $\mathrm{g} /\left(\mathrm{m}^{2} \times \mathrm{h}\right)$, were evaluated by weight losses in specimens $(\Delta m, \mathrm{~g})$ by equation below:

$$
K=\frac{\Delta m}{S \cdot \tau}
$$

where: $\quad S$ - specimen area, $\mathrm{m}^{2}$;

$\tau$ - test period, h.

Protective effect of bactericidal inhibitor (Z, \%) being calculated by equation:

$$
Z(\%)=\frac{K_{0}-K_{\text {in }}}{K_{0}} \cdot 100,
$$

where: $K_{0}$ and $K_{\text {in }}$ - corrosion rates in non-inhibited and inhibited solutions, respectively.

In the second case, analytical studies were carried out according to procedure in GOST 4011 [31], and they included photocolorimetry measurements of optical densities in coloured solutions due to forming of complex compound between sulfosalicylic acid and iron ions. Final result of this analysis was optical density value of a sample containing coloured complex, excluding colour contributions from used reagents, the sample itself, and iron traces therein. This true optical density value, $A_{\text {tr }}(\mathrm{n} .2)$, was calculated by equation:

$$
A_{\mathrm{tr}}(\mathrm{n} .2)=A_{\mathrm{av}}(\mathrm{n} .2)-A_{\mathrm{av}}(\mathrm{n} .1)-A_{\mathrm{av}}(0.2)+A_{\mathrm{av}}(0.1) \text {, }
$$

where: "n.1" and "n.2" are analysed solution samples without and with sulfosalicylic acid, and " $0.1 "$, " 0.2 " relate to distilled water samples, "av" - average. Total iron mass concentration in sample then was found using a calibration curve, and was recalculated to iron concentration in solution being analysed.

Steel Grade Sw08A plasticity was evaluated using IH 5128M tool by number of bends until destroying of wire specimens $(L=11 \mathrm{~cm})$ in initial state $\left(B_{0}\right)$ and after their exposure in solution with inhibitor or bactericidal additive $\left(B_{\text {inh }}\right)$. Protective effect of additives for steel embrittlement $\left(Z_{\mathrm{emb}}, \%\right)$ was calculated by equation:

$$
Z_{\text {emb }}(\%)=\frac{B_{\text {inh }}-B_{\text {bg }}}{B_{0}-B_{\text {bg }}} \cdot 100,
$$

where: $B$ - number of wire bends before destroying, unit. 
In this study, steel wire Grade Sw08A could stand 20 bends before destroying in initial state, i.e. $B_{\text {init }}=20$ in all tests.

\section{Experimental Results and Discussion}

\section{Assessment of bactericidal features}

Measuring of optical density of bacteria inoculated media, according to data in literature [32], allows indirect evaluation of suspended (plankton) biomass quantity. Hence, while observing dynamics of changing this parameter, one may evaluate relative augmentation of bacteria quantity that float in nutrient medium.

Experimental results of optical density measurements in solutions without or with additives being examined, and calculated values of bacterial growth inhibition rates as well, are presented in Figure 3.
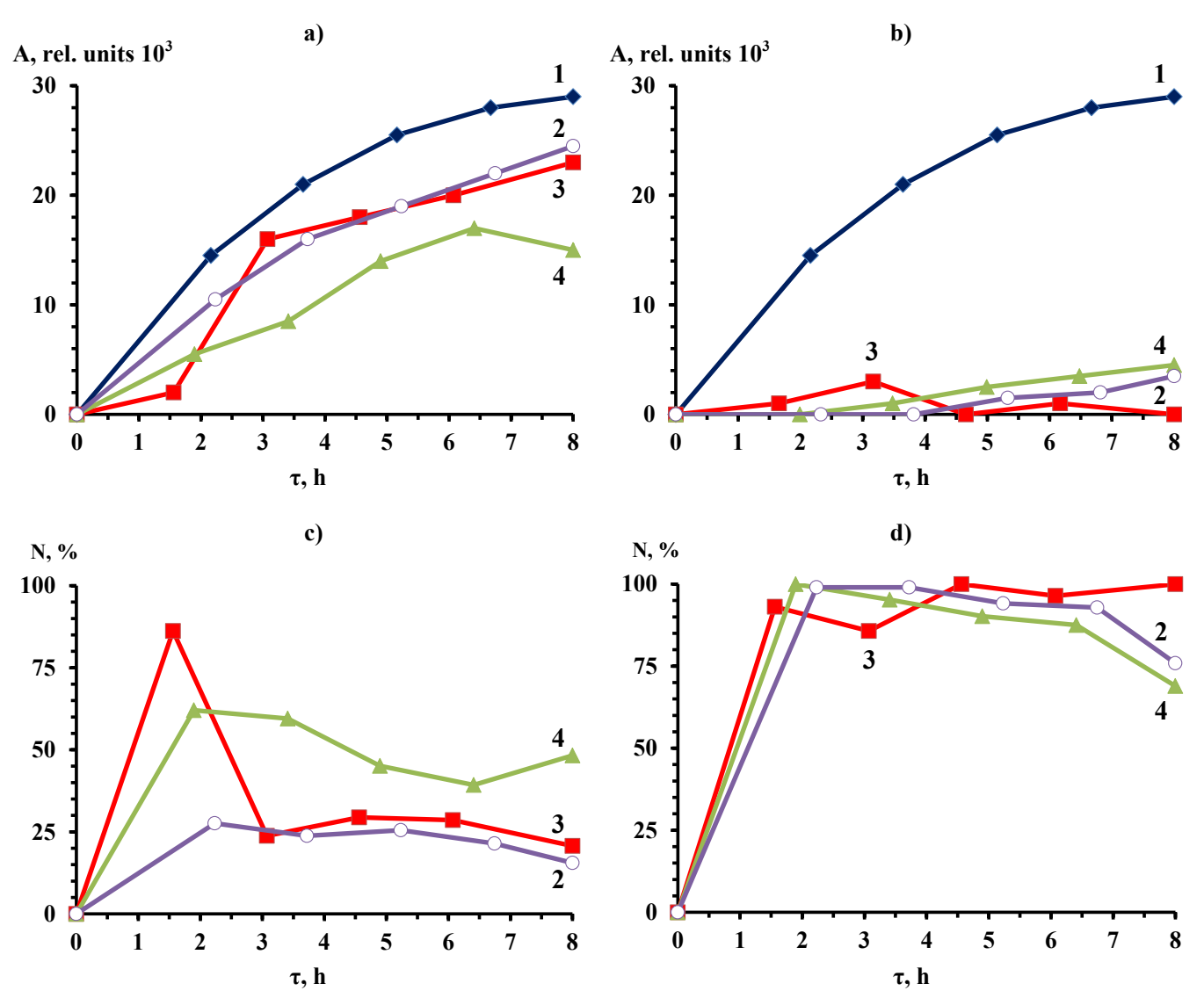

Figure 3. Kinetic dependences of optical density of SRB Inoculated Solutions $(a, b)$ with no bactericide (1) and with additives "B1" (2), "B2" (3), and "B3" (4), and also bacterial growth inhibition rates $(\mathrm{c}, \mathrm{d})$ when $0.001 \%(\mathrm{a}, \mathrm{c})$ or $0.01 \%(\mathrm{~b}, \mathrm{~d})$ of reagent was added.

Each experimental point in these curves corresponds to arithmetic average of three successive optical density measurements of one test solution. Since these solutions would impossible to use for experiment after measurement procedure (strict anaerobic conditions 
required), the test solution at the start of the experiment was divided to several tubes than were then sealed with plugs. So, different experimental points in any one curve represent results of parallel optical density measurements in any one test solution at different exposure time.

Quantity growth of biomass in the background medium along with the time is shown by ascending course of the Curve 1 (Figure 3), at that dependence obtained is an average result of not less than 8 parallel tests.

When $0.001 \%$ of reagents was added to the medium, which approximately corresponded to $C_{\text {inh }}=10 \mathrm{mg} / \mathrm{l}$, decreasing growth rate in optical density of inhibited nutrient medium, compared to background fluid, was clearly observed. Such behaviour supported demonstration of bactericide features by additives. Thus, biocide "B1" already after $2 \mathrm{~h}$ exposure led to decrease of suspended biomass quantity by a quarter. Reagent "B2" slightly worse proved itself during initial stage of the study, but after $4 \mathrm{~h}$ exposure it already was comparable to "B1" in efficiency. Bacterial growth inhibition rate in both these compositions was approximately 15 to $20 \%$ after $8 \mathrm{~h}$. Additive "B3" demonstrated the best results of all; at $C=0.001 \%$ it achieved biomass growth decrease virtually by a half.

Increasing of introduced composition concentrations to $0.01 \%$ resulted in quality changes in their biocide features: in inhibited solutions, SRB virtually could not grow (Figures $3 \mathrm{~b}$ and $3 \mathrm{~d}$ ). For all compositions, initial $N$ values were not less than $80 \%$, and it only slightly decreased after $8 \mathrm{~h}$ testing with "B1" and "B2".

Further studies of bactericide features at greater concentrations proved to be unsuccessful using optical technique, due to rapid increase of optical density values in solution along with the time. Such significant changes in properties of the test medium were apparently associated with generation of additional barriers to light passage through the liquid, particularly formation of bactericide colloid solution in water.

Extension of test period to 24 hours was also inappropriate, due to formation of thin suspension consisting of light-yellow to grayish coloured particles in test media. Evidently, this was a result of low-soluble substances in chemical interaction between medium components and SRB metabolites. To support the suggestion, optical density measurements in sterile nutrient medium were conducted. As it was found in these tests, optical density in the solution did not increase during 7 days of exposure, indicating that no insoluble compounds were formed in sterile solution itself along with the time.

Attempts to use filtration or centrifugation of test solutions before testing and straight before measurements brought no reproducible results during all course of the experiment exceeding 8 hours.

Besides, for 8 hour exposure, SRB could not evolve enough $\mathrm{H}_{2} \mathrm{~S}$ into the medium, so that reliable titrimetric techniques might be employed. 


\section{Corrosion tests}

\section{A) Deaerated nutrient medium}

Corrosion rate in oxygen-depleted nutrient medium was determined using three parallel methods:

- LPR measurement of steel electrodes;

$-C\left(\mathrm{Fe}_{\text {total }}\right)$ determination in solution after test;

- gravimetric evaluation of weight loss in witness specimens.

Protective effect of bactericides was calculated by standard equation, while in the first case, $\mathrm{K}$ was calculated by integration of momentary corrosion rate for the entire measurement time interval, and in case of analytical studies, CI efficacy was determined based on $C\left(\mathrm{Fe}_{\text {total }}\right)$ values in background and inhibited media. Dependence of optical density in coloured complex Fe solutions on $C\left(\mathrm{Fe}_{\text {total }}\right)$ value, which was required to be determined according to measurement method by [31], was expressed as:

$$
A=0.1194 \cdot C\left(\mathrm{Fe}_{\text {total }}\right) \text {, at } R^{2}=0.9999
$$

Test results obtained and calculations are represented in Figure 4.

It was established by these testing that at low $\mathrm{C}_{\text {inh }}$ in the solution, Additive "B1" have $Z \leq 20 \%$, while values obtained using the three methods have good consistency. Increasing CI concentration by one order (to $0.01 \%$ ) results in regular growing of $Z$ up to range $56.9 \%$ to $68 \%$, and only at $C_{\text {inh }}=0.1 \%$, the composition can provide sufficient protection, demonstrating $Z=92.2$ to $94.6 \%$.
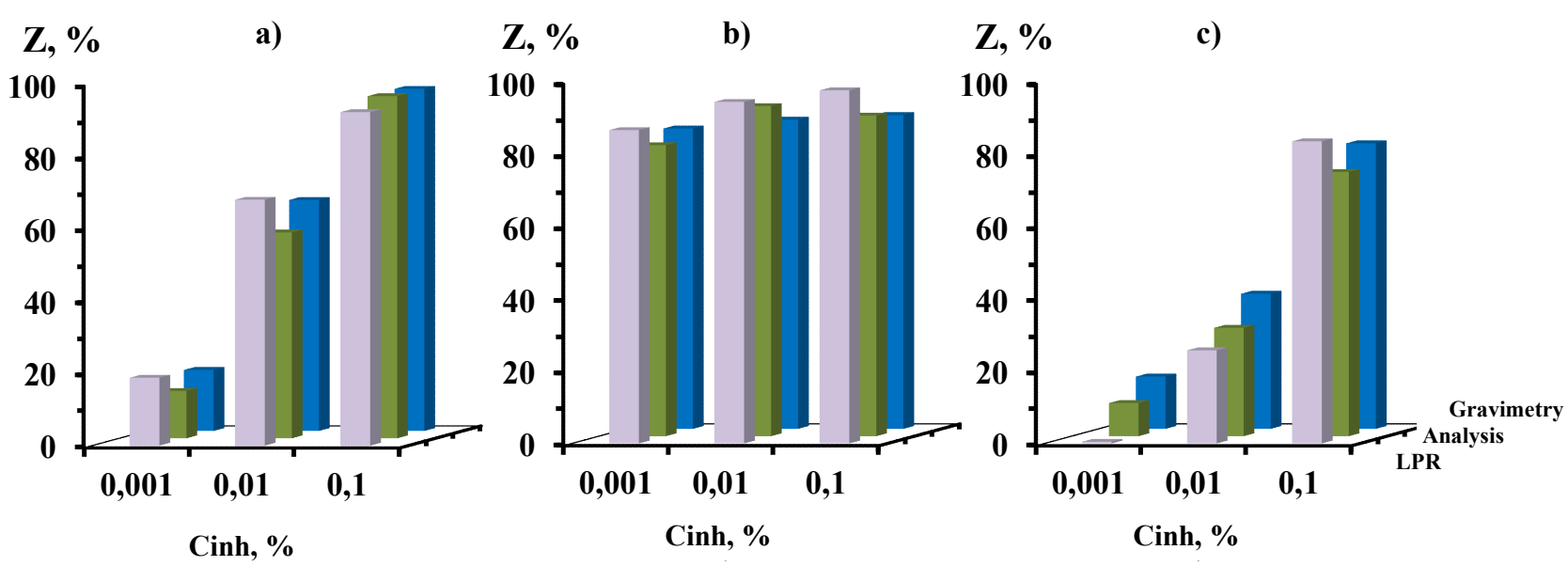

Figure 4. Protective effects of bactericides "B1" (a), "B2" (b), and "B3" (c) after 7 day tests in deaerated nutrient medium. Results of LPR measurements, $C\left(\mathrm{Fe}_{\text {total }}\right)$ analyses in solutions, and gravimetric tests. 
The best efficacy among CI tested was demonstrated by bactericide "B2": already at $C_{\text {inh }}=0.001 \%, Z$ values are within satisfactory interval $(80.5 \%$ to $86.7 \%)$. At greater $C_{\text {inh }}=0.01 \%$, efficacy of the additive increased to $85.5 \%$ to $94.5 \%$, and similar values were determined in the presence of $0.1 \%$ "B2" in the solution.

Additive "B3" demonstrated a weak protection, especially at low reagent concentrations. Thus, in case of $C_{\text {inh }}$ (B3) $=0.001 \%$, even some stimulating influence was observed based on LPR measurement data. However, dissolved iron quantity determined in this solution after finish of the experiment was slightly lower than in the background medium, so $Z$ value of chemical analysis data was equal to $9.2 \%$. Direct gravimetric measurements also witnessed low protection ability of "B3" $(Z=14.5 \%)$.

Ten-fold increasing of CI content to $0.01 \%$ in the solution had a weak effect, since corrosion rate decreased by $25.8 \%$ to $37.4 \%$ only, which is obviously unsatisfactory rate for an industrial additive. It should be noted that even at $C_{\text {inh }}=0.1 \%$, averaged $Z$ value based on results of the three methods was below $80 \%$, which value was set as minimum required CI efficacy rate by a number of petroleum and gas companies.

Despite of known limits and presumptions inherent to each of applied methods of examination, obtained test results have good consistency and so, allow reliable efficacy assessments for inhibiting compositions under study.

\section{B) $\mathrm{CO}_{2}$ Saturated Nutrient Medium}

Presence of $\mathrm{CO}_{2}$ not rarely was recorded in living environments of SRB [33]. Besides, $\mathrm{CO}_{2}$ can saturate electrolytes via direct diffusion there from ambient air, and often represents an immediate metabolite of bacteria in question. When organic components, such as lactate, butyrate, propionate, etc., are present in an environment, SRB can use them as electron donors, by oxidizing them finally to acetate or even $\mathrm{CO}_{2}[15,34]$ :

$$
\mathrm{Fe}+2 \mathrm{C}_{3} \mathrm{H}_{5} \mathrm{O}_{3}^{-}+\mathrm{SO}_{4}^{2-} \rightarrow \mathrm{FeS}+2 \mathrm{CH}_{3} \mathrm{COO}^{-}+2 \mathrm{CO}_{2}+\mathrm{H}_{2}+2 \mathrm{OH}^{-}
$$

But when the above organic substances are lacking or scarce in an environment, SRB are capable to reverse their metabolism and use $\mathrm{CO}_{2}$ as a source of carbon [35]. In the latter case, synergetic effect of interaction is observed: on one hand, $\mathrm{CO}_{2}$ is itself an aggressive component of corrosive environment, on other hand, its presence may promote increased bacterial growth rate and development of biocorrosion [36].

In this connection, a study of bactericide and anti-corrosion features of tested additives in SRB inoculated and $\mathrm{CO}_{2}$ saturated at 1 atm environment was of interest. In addition to previous gravimetric tests and analytical measurements, in this test series, impact of operational environment on plastic properties of carbon steel Sw08A was also investigated. Experiments were carried out at different exposure periods on steel specimens immersed in the electrolyte $(3,5$, and 7 days), and the resulting data obtained are represented in Table 1. 
Table 1. Protective efficacy of bactericides "B1", "B2", and "B3". Exposure of steel in SRB inoculated nutrient medium, at $p_{\mathrm{CO}_{2}}=1 \mathrm{~atm}$.

\begin{tabular}{|c|c|c|c|c|c|c|c|c|c|c|}
\hline \multirow{2}{*}{ CI } & \multirow{2}{*}{$C, \%$} & \multicolumn{3}{|c|}{$\begin{array}{c}3 \text { day } \\
K=0.044 \mathrm{~g} /\left(\mathrm{m}^{2} \cdot \mathrm{h}\right)\end{array}$} & \multicolumn{3}{|c|}{$\begin{array}{c}5 \mathrm{day} \\
K=0.036 \mathrm{~g} /\left(\mathrm{m}^{2} \cdot \mathrm{h}\right)\end{array}$} & \multicolumn{3}{|c|}{ 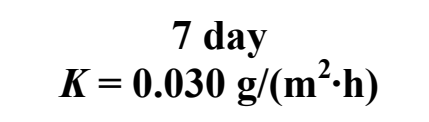 } \\
\hline & & $\underset{\text { grav }}{Z_{\text {o }}}$ & $Z_{\text {an, }} \%$ & $\begin{array}{c}Z_{\text {embr }}, \\
\%\end{array}$ & $\underset{\text { grav }}{Z_{\text {o }}}$ & $Z_{\text {an, }} \%$ & $\begin{array}{c}Z_{\text {embr }}, \\
\%\end{array}$ & $\underset{\text { grav }}{Z_{\text {o }}}$ & $Z_{\text {an }}, \%$ & $\underset{\quad Z_{\text {embr }},}{\%}$ \\
\hline \multirow{3}{*}{ "B1" } & 0.001 & 6.8 & 22.7 & 0 & Stim. & 4.3 & 0 & Stim. & Stim. & 25 \\
\hline & 0.01 & 45.5 & 41.2 & 91.7 & 47.9 & 45.4 & 91.7 & 60.2 & 51.8 & 58.3 \\
\hline & 0.1 & 86.4 & 96.4 & 91.7 & 88.9 & 75.1 & 91.7 & 86.7 & 77.4 & 91.7 \\
\hline \multirow{3}{*}{ "B2" } & 0.001 & 9.1 & 6.8 & 58.3 & Stim. & 21.0 & 33.3 & 3.3 & 26.4 & 33.3 \\
\hline & 0.01 & 38.6 & 25.5 & 66.7 & 52.9 & 42.0 & 41.6 & 36.7 & 40.9 & 33.3 \\
\hline & 0.1 & 90.9 & 93.2 & 91.7 & 83.3 & 77.8 & 100 & 90.0 & 83.2 & 100 \\
\hline \multirow{3}{*}{ "B3" } & 0.001 & 25.0 & 16.2 & 0 & 22.2 & 17.8 & 0 & 13.3 & Stim. & 0 \\
\hline & 0.01 & 36.4 & 50.8 & 33.3 & 72.5 & 51.8 & 25.0 & 63.3 & 48.1 & 8.3 \\
\hline & 0.1 & 47.7 & 75.3 & 91.7 & 0 & 19.7 & 91.7 & Stim. & 29.5 & 58.3 \\
\hline
\end{tabular}

In general case, addition of $\mathrm{CO}_{2}$ to the nutrient medium resulted in decreasing protective features of substances being studied. For example, protection efficacy of "B1" at $\mathrm{C}_{\text {inh }}=0.001 \%$ was insignificant and unstable $(0-23 \%)$, wherein longer exposure periods evidently tended to stimulate corrosion. Hence, such $\mathrm{C}_{\text {inh }}$ was insufficient for creating a stable protective film.

By increasing introduced concentration of this bactericide, it was possible to achieve corrosion inhibition by $41.2 \%$ to $47.9 \%$ at 3 or 5 days of exposure, and $Z_{\text {embr }}$ was close to maximum achieved value. Some minor increase of protective capacity of "B1" was observed when the experiment was prolonged to 7 days, but then steel embrittlement protection feature decreased $\left(Z_{\mathrm{embr}}=58.3 \%\right)$. Introduction of $0.1 \%$ "B1" was most effective, since only in this case the above bactericidal inhibitor is capable to retard steel corrosion and embrittlement processes by an order $(Z \approx 90 \%)$.

Corrosion protective efficacy of Bactericide "B2" was small in short exposure conditions: at $C_{\mathrm{inh}}=0.001 \%, Z$ not exceeded $9.1 \%$, and at $0.01 \%$ was $38.6 \%$. In case of longer testing, presence of small "B2" concentrations according to gravimetry results, had virtually no effect on steel $K$, though in this case was detected by $21 \%$ to $26.4 \%$ less dissolved iron in the solution, than in the background. We may suggest that iron, in this case, accumulates in corrosion product layer, which is not protective, since value of $Z_{\text {grav }} \approx 0 \%$. 
More stable protection features were provided only at $C_{\text {inh }} \geq 0.01 \%$, and satisfactory efficacy of the additive was observed only at maximum test concentration, $0.1 \%$.

Bactericidal Additive "B3", which had shown the least efficacy among all in the previous series, also did not show significant inhibiting features in the present test series. Corrosion protection effects of "B3" in carbon steel at $C_{\mathrm{inh}}=0.001 \%$ were within range of unstable values, although slightly greater than in "B2". In this case, corrosion damage retarded not more than by a quarter, and steel plasticity remained at background medium level. The latter witness that "B3" at low concentration did not create protective film, just as other additives being studied. At increased "B3" concentration to $0.01 \%$, protective effects increase consistently with results of all performed measurements and achieve $36.4 \%$ to $72.5 \%$.

Surprising results were obtained at maximum "B3" concentration: the additive could not demonstrate expected high degree of protection, which tended, besides, to decrease along with the time.

\section{Conclusions}

1. Optical density value may be applied as a criterion for bactericidal feature assessment of reagents. At that, duration of testing and ambient conditions should support colloidal stability of analysed solution.

2. Among substances being studied, Soncide 8102B demonstrated the best antimicrobial efficacy, which at $C_{\text {inh }}=0.01 \%$ can virtually completely suppress development of biota. This additive also showed good inhibiting ability: at $C_{\text {inh }}=0.001 \%$, corrosion rate in carbon steel in the presence of SRB decreases not less than by $83 \%$.

3. Addition of $\mathrm{CO}_{2}$ into $\mathrm{SRB}$ inoculated nutrient medium is capable to increase biocorrosion of steel, also due to stimulation of growth and development of bacteria. In general, simultaneous presence of $\mathrm{CO}_{2}$ and $\mathrm{SRB}$ in the electrolyte appreciably decreased corrosion inhibition efficacy by all bactericides being studied.

4. Appropriateness and relevance of continued complex studies on microbiologic corrosion of pipeline steel was supported, as well as revealing its kinetic behaviour for purposes of justified planning of engineering diagnostics in TGP, development of prevention methods against SCC and corrosion in trunk gas transportation objects, and also development of express techniques for assessment of corrosion and bacteriological properties of ground and under-film electrolytes.

\section{References}

1. A.A. Gerasimenko, G.V. Matjusha, T.A. Andryushenko, N.B. Lukina and R.L. Pelah, "Microbiological corrosion and protection", Korroz.: Mater., Zashch., 2003, no. 1, 3741 (in Russian).

2. M.V. Vigdorovich, V.I. Vigdorovich, A.V. Ryazanov and A.N. Zavershinskii, "Suppressing sulfate-reducing bacteria, as well as hydrogen diffusion through steel, by inhibitors of AMDOR IC type", Prot. Met., 2007, 43, no. 1, 95-99. 
3. S.N. Kuimov, S.V. Bausov, A.I. Istomin, T.K. Korostelyova and V.V. Podol'skaya, "Informational and analytical provision for technical conditioning of gas pipelines subject to stress-corrosion cracking", Vesti Gazovoy Nauki, 2016, 27, no. 3, 131-138 (in Russian).

4. I.A. Kozlova, Zh.P. Kopteva, L.M. Purish, E.I. Andreyuk, N.S. Pogrebova and O.H. Tuovinen, "Microbial corrosion and protection of underground metal construction", Praktika protivokorrozionnoi zashchity, 1999, no. 3, 21-27 (in Russian).

5. H.A. Videla and L.K. Herrera, "Microbiologically influenced corrosion: looking to the future", Int. microbiol., 2005, 8, 169-180.

6. R. Javaherdashti, "A review of some characteristics of MIC caused by sulfatereducing bacteria: past, present and future, Anti-Corros. Meth. Mater., 1999, 46, p. 173-180.

7. K.M. Usher, A.H. Kaksonen, I. Cole and D. Marney, "Critical review: Microbially influenced corrosion of buried carbon steel pipes", Int. Biodeterior. Biodegrad., 2014, 93, 84-106.

8. V.L. Rainha and I.T.E. Fonseca, "Kinetic studies on the SRB influenced corrosion of steel: a first approach", Corros. Sci., 1997, 39, no. 4, 807-813.

9. A.A. Chirkunov, R.V. Kashkovskiy and A.V. Goncharov, Korroz.: Mater, Zashch., 2013, no. 1, 44-47 (in Russian).

10. M.V. Ivanova, Yu.D. Solodov, A.F. Zainullin and R.V. Kashkovskiy, Gas Industry of Russia, 2014, 715, no. 12, 78-79 (in Russian).

11. M.V. Ivanov, "The role of microorganisms in the formation of hydrogen sulphide, The role of microorganisms in the cycle of gases in nature", Moscow, Nauka, 1980, $114 \mathrm{pp}$. (in Russian).

12. X. Chen, G. Wang, F. Gao, Y. Wang and C. He, "Effects of sulphate-reducing bacteria on crevice corrosion in X70 pipeline steel under disbonded coatings", Corros. Sci., 2015, 101, 1-11.

13. A.I. Marshakov, I.V. Ryakhovskikh, V.E. Ignatenko, M.A. Petrunin, R.I. Bogdanov, Vo Thanh Thien and Yu.I. Kuznetsov, "Development of inhibiting compositions aimed at preventing stress corrosion c racking of gas mains", Vesti Gazovoy Nauki, 2016, 27, no. 3, 48-63 (in Russian).

14. H. Venzlaff, D. Enning, J. Srinivasan, K.J.J. Mayrhofer, A.W. Hassel, F. Widdel and M. Stratmann, "Accelerated cathodic reaction in microbial corrosion of iron due to direct electron uptake by sulfate-reducing bacteria", Corros. Sci., 2013, 66, 88-96.

15. T. Liu and Y.F. Cheng, "The influence of cathodic protection potential on the biofilm formation and corrosion behaviour of an X70 steel pipeline in sulfate reducing bacteria media", J. Alloys Compd., 2017, 729, 180-188.

16. S.V. Alimov, S.V. Arabei, I.V. Ryakhovskikh, T.S. Esiev, S.V. Nefedov, I.I. Gubanok and P.V. Abrosimov, "Concept of diagnosis and repair of main gas pipelines in regions with a high predisposition to stress corrosion, GAS Industry of Russia, 2015, 724, 10 15 (in Russian). 
17. V.E. Ignatenko, Yu.I. Kuznetsov and A.B. Arabei, "Application of SSRT to estimate the effect of corrosive medium on the liability of X70 pipe steel to stress corrosion cracking”, Int. J. Corros. Scale Inhib., 2013, 2, no. 4, 318-336. doi: 10.17675/23056894-2013-2-4-318-336

18. I.V. Ryakhovskikh, R.I. Bogdanov, T.S. Esiev and A. Marshakov, "Stress corrosion cracking of pipeline steel in near-neutral $\mathrm{pH}$ environment", Proceedings of Materials Science \& Technology, 2014, Pittsburgh, PA, USA, V. 1, pp. 807-815.

19. R. Kashkovskiy, "Estimation of corrosion products and inhibitor films contributions to total protective effect", J. Corros. Sci. Eng., 2016, 19.

20. A.M. Badawi, M.A. Hegazy, A.A. El-Sawy, H.M. Ahmed and W.M. Kamel, "Novel quaternary ammonium hydroxide cationic surfactants as corrosion inhibitors for carbon steel and as biocides for sulfate reducing bacteria (SRB)", Mater. Chem. Phys., 2010, 124, no. 1. 458-465.

21. S.N. Litvinenko, Zashchita nefteproduktov ot deistviya mikroorganizmov (Protection of petroleum products against the action of microorganisms), Moscow, Khimiya, 1977, 143 pp. (in Russian).

22. N.G. Ibragimov, A.R. Hafizov and V.V. Shajdakov, Oslozhneniya $v$ neftedobyche (Complications in oil production), Ufa, Monograph, 2003, 302 pp. (in Russian).

23. R. Kashkovskiy, "Estimation of corrosion products and inhibitor films contributions to total protective effect", NACE - International Corrosion Conference Series, 2016, Vol. 2, 1448-1461.

24. V.E. Ignatenko, Vo Tien, A.I. Marshakov, Yu.I. Kuznetsov, A.V. Muradov and I.V. Ryakhovskikh, "Effect of organic corrosion inhibitors on rate of crack growth in pipe steel X70 in weakly acidic solution", Korroz.: Mater, Zashch., 2016, no. 11, 2733 (in Russian).

25. R.V. Kashkovskiy, Yu.I. Kuznetsov and N.P. Andreeva, Korroz.: mater., zashch., 2012, no. 7, 19 (in Russian).

26. J.R. Postgate, The sulphate-reducing bacteria (second edition), Cambridge University Press, Cambridge, UK, 1984, 208.

27. GOST (Russian Standard) 1050-2013, Carbon structural quality steel gauged bars with special surface finish. General specifications, Standartinform, Moscow, 2014, p. 32 (in Russian).

28. GOST (Russian Standard) 2246-70, Welding steel wire. Specifications, Standartinform, Moscow, 2008, p. 20 (in Russian).

29. Yu.I. Kuznetsov, R.V. Kashkovskiy and R.K. Vagapov, "Effect of volatile inhibitors structure and medium properties on hydrogen sulfide corrosion of steel equipment and pipelines", EUROCORR-2010, Moscow, Russia, 2010, p. 3546.

30. R.V. Kashkovskiy and Yu.I. Kuznetsov, Int. J. Corros. Scale Inhib., 2012, 1, 117-129. doi: $10.17675 / 2305-6894-2012-1-2-117-129$

31. GOST (Russian Standard) 4011-72, Drinking water. Methods for determination of total iron, Standartinform, Moscow, 2010, p. 7 (in Russian). 
32. R.V. Kashkovskiy, Ingibirovanie serovodorodnoi korrozii nizkouglerodistykh stalei letuchimi aminami (Inhibition of hydrogen sulfide corrosion of low carbon steel by volatile amines), $\mathrm{PhD}$ dissertation, Frumkin Institute of Physical Chemistry and Electrochemistry Russian Academy of Sciences, Moscow, 2011 (in Russian).

33. M.M. Fan, H.F. Liu and Z.H. Dong, "Microbiologically influenced corrosion of X60 carbon steel in $\mathrm{CO}_{2}$-saturated oilfield flooding water", Mater. Corros., 2013, 64, 242 246.

34. O.O. Oyekola, R.P. van Hille and S.T.L. Harrison, "Effect of sulphate concentration on the community structure and activity of sulphate reducing bacteria", Adv. Mater. Res., 2007, 20-21, 513-515.

35. G. Muyzer and A.J.M. Stams, "The ecology and biotechnology of sulphate-reducing bacteria", Nat. Rev. Microbiol., 2008, 6, 441-454.

36. H. Liu and Y.F. Cheng, "Mechanism of microbiologically influenced corrosion of X52 pipeline steel in a wet soil containing sulfate-reduced bacteria", Electrochim. Acta, 2017, 253, 368-378. 